\title{
Extrathoracic metastases of thymic origin: a review of 35 cases
}

\author{
Tudor Vladislav ${ }^{1}$, Rohit K Jain ${ }^{1}$, Rudy Alvarez ${ }^{1}$, Rutika J Mehta ${ }^{1}$, Yesim Gökmen-Polar ${ }^{2}$, \\ Kenneth A Kesler ${ }^{3}$, John D Henley ${ }^{4}$, Patrick J Loehrer $\mathrm{Sr}^{2}$ and Sunil Badve ${ }^{1}$ \\ ${ }^{1}$ Department of Pathology and Laboratory Medicine, Indiana University School of Medicine and Indiana \\ University Simon Cancer Center, Indianapolis, IN, USA; ${ }^{2}$ Department of Internal Medicine, Indiana \\ University School of Medicine and Indiana University Simon Cancer Center, Indianapolis, IN, USA; \\ ${ }^{3}$ Department of Surgery, Indiana University School of Medicine and Indiana University Simon Cancer Center, \\ Indianapolis, IN, USA and ${ }^{4}$ Department of Pathology, Columbus Regional Hospital, Columbus, IN, USA
}

\begin{abstract}
Thymic tumors are categorized as types A, AB, B1, B2, B3, and thymic carcinoma under the World Health Organization (WHO) classification. Thymomas are typically slow growing tumors that predominantly involve the surrounding structures through direct invasion, while thymic carcinomas tend to be more aggressive. A significant number of patients are asymptomatic and can present with metastases as the first presentation. The exact incidence of extrathoracic metastases from thymoma is not known. This study describes a series of 35 cases of histologically documented metastatic thymomas and thymic carcinomas at extrathoracic sites. These cases were classified according to the current World Health Organization (WHO) classification criteria, and we present their clinical data as well as discuss the differential diagnoses of these lesions. Our study shows that all types of thymic tumors, regardless of histologic type, can be associated with invasion and metastases to thoracic and extrathoracic sites.
\end{abstract}

Modern Pathology (2012) 25, 370-377; doi:10.1038/modpathol.2011.178; published online 11 November 2011

Keywords: extrathoracic metastases; thymic carcinoma; thymoma

Thymoma, a neoplastic transformation of the epithelial cells of the thymus gland, accounts for $\sim 40 \%$ of all mediastinal tumors. ${ }^{1}$ It is one of the lesions that should be considered in the differential diagnosis of an anterior mediastinal mass. Thymomas have been associated with different paraneoplastic syndromes such as myasthenia gravis, polymyositis, lupus erythematosis, rheumatoid arthritis, and pure red cell aplasia. ${ }^{2}$ Thymomas are typically very slow growing tumors that predominantly involve the surrounding structures through direct invasion. Thymic tumors are categorized as types A, AB, B1, B2, B3, and carcinoma by the 2004 World Health Organization (WHO) classification of thymic epithelial tumors. ${ }^{3}$ Approximately $30 \%$ of thymic carcinoma patients are asymptomatic when diagnosed. ${ }^{2}$

Correspondence: Professor S Badve, MD, FRCPath, Department of Pathology and Laboratory Medicine, Indiana University School of Medicine and Indiana University Simon Cancer Center, 350 West 11th Street, IUHPL 4050, Indianapolis, IN 46202, USA.

E-mail: sbadve@iupui.edu

Received 10 August 2011; revised 21 September 2011; accepted 21 September 2011; published online 11 November 2011
It is the most aggressive variant invading surrounding structures with metastases, ${ }^{2}$ although embolic metastases of thymic carcinoma leading to extrathoracic metastases are very rare. ${ }^{4}$ Since, thymic cancers invade locally, diagnoses of metastases are difficult. Locally advanced thymic tumors often present as pleural plaques, which can be misdiagnosed as lung metastases on imaging studies. Thus, it becomes very important to appropriately define metastases in these tumors. For this reason, we defined only lesions outside the thorax that were histologically similar to the primary thymic tumors as metastases.

Although the exact incidence of extrathoracic metastases from thymoma is not known, in 1983, Ichino et $a l^{5}$ documented 83 cases in the literature. However, most of the metastatic sites were not biopsied and histology was not available. In addition, the older literature does not make a distinction between epithelial lesions (true thymic tumors) and other neoplasms arising in the region of thymus. In any event, these studies suggest liver, bone, and lymph nodes as common sites of extrathoracic metastases of malignant thymoma. ${ }^{4-6}$ Moreover, 
renal and splanchnic metastases as well as cerebral metastasis, although quite rare, have also been reported. ${ }^{5}$ In older literature, a majority of thymomas with metastases were described as epithelial type without any further categorization. ${ }^{5}$ More recently, Huang et $a l^{7}$ described a series of 120 thymic neoplasms treated at Memorial Sloan-Kettering Cancer Center between 1995 and 2006. Only eight of these patients developed distant progression even when lung was included as one of the sites of distant relapse. All the cases with extrathoracic involvement were thymic carcinomas; however, none were biopsied to histologically confirm the metastases.

This study describes a series of 35 cases of histologically documented metastatic thymic tumors at extrathoracic sites, classifies them according to latest WHO classification criteria, compares different clinical data, and discusses the differential diagnoses of these lesions. It documents that all types of thymic tumors can be associated with extrathoracic metastases.

\section{Materials and methods}

Institutional Review Board approval was obtained before the initiation of the study. The Indiana University Pathology Department database contains $>600$ independent cases of thymic neoplasms diagnosed between the years 1985 and 2011. A search of this database was done to identify all cases of thymic tumors with metastases. All cases with only intrathoracic metastases were excluded, leading to the identification of 51 cases. Metastasis had been histological confirmed in 43 cases. Of these, slides from 35 cases were available for review. The demographic and clinical data were collected for these selected cases. The variables of interest obtained were age, sex, date of initial diagnosis, clinical features at time of presentation, type of primary tumor, and site of extrathoracic metastases. WHO (2004) thymoma classification ${ }^{3}$ was used to identify the histology type of the metastatic lesion on hematoxylin and eosin-stained slides. Where possible, the histological features of the primary and metastatic lesions were compared.

\section{Results}

The review led to the identification of 35 cases-22 patients with thymic carcinoma and 13 patients with thymoma. These cases are detailed in Table 1 and are the subject of this study. The age range was 23-93 years with a mean of 50.4 years. The male-tofemale ratio observed was $\sim 2: 1$. Twenty-three patients had metastases to multiple sites while 11 had single metastases (data missing for one patient).

At the time of diagnosis of primary thymic tumor, epigastric discomfort, shortness of breath, and persistent cough were a few of the prominent symptoms seen in the patients. Superior vena cava obstruction was observed in two patients. Myasthenia gravis was noted in 4 of 35 patients (one case each of types B1 and B2, and two cases of B3).

Archival slides were reviewed and tumors categorized according to the current WHO classification. ${ }^{8}$ In many cases, this categorization was based on biopsy material and may not represent the true nature of the tumor. Histologically, the tumors were classified as thymoma type A $(n=1)$ (Figure 1), type B1 $(n=3)$, type B2 $(n=3)$ (Figure 2$)$, type B3 $(n=6)$, and thymic carcinoma $(n=22)$ (Figure 3$)$. None of the metastatic cases was associated with type $A B$ histology. Among the thymic carcinomas, there were 11 cases of undifferentiated carcinoma (Figure 3a), 4 cases of squamous cell carcinoma, 4 cases of neuroendocrine carcinomas, 2 cases of mixed small cell undifferentiated squamous cell carcinoma (Figure $3 \mathrm{~b}$ ), and 1 clear cell carcinoma. The average interval for thymomas was 2.5 years while the average interval for thymic carcinoma was 0.6 years. Of the six patients with B3, one had synchronous metastasis; overall average interval was 3.9 years. Of the six patients with B1 or B2 thymoma at presentation, four had synchronous metastasis. However, it is important to note that in many of these patients, needle biopsy specimens were the only tissues available for review. In these cases, a coexisting higher grade lesion cannot be excluded.

The primary tumor was available for review in only 8 of the 35 cases. In all of the cases, the histology of the metastatic tumor was very similar to that of the primary tumor. However, in one case, relative depletion of the lymphoid population was noted.

The time interval from the diagnosis of primary thymic tumor to metastasis ranged from synchronous to 17 years (average 3.6 years). Eighteen patients presented with synchronous metastasis. In nine patients, the metastasis was metachronous and, in eight patients, time of metastasis was not documented. The time to metastasis in the patients with metachronous metastasis was 1.7 years (range 1-3 years) for patients with thymic carcinoma, while it was 17 years $(n=1)$ and 3 years (range $0.5-6$ years) for patients with B1 and B3 thymomas, respectively. Of the three cases of B2, two presented with stage IV disease and, in one case, the time to metastasis was not available.

Most patients with extrathoracic metastasis had multiple metastases involving intrathoracic and extrathoracic sites. The predominant presenting features in patients with synchronous metastasis were related to general discomfort including weight loss and fatigue; pulmonary symptoms, such as shortness of breath, cough, hemoptysis, and hoarseness; as well as other symptoms related to metastasis, such as bone pain, lymphadenopathy, and nodules on scalp and chest wall. Myasthenia gravis symptoms were noted in one patient. 
Table 1 Clinical and pathologic parameters of the 35 cases with extrathoracic metastases

\begin{tabular}{|c|c|c|c|c|c|c|c|c|c|c|c|}
\hline $\begin{array}{l}\text { Age } \\
\text { (years) }\end{array}$ & Sex & $\begin{array}{l}\text { Date of } \\
\text { diagnosis }\end{array}$ & $\begin{array}{l}\text { Tumor } \\
\text { type }\end{array}$ & $\begin{array}{c}\text { Stage at } \\
\text { diagnosis }\end{array}$ & $\begin{array}{l}\text { Size of } \\
\text { primary }\end{array}$ & $\begin{array}{l}\text { Symptoms at } \\
\text { presentation }\end{array}$ & $\begin{array}{l}\text { Symptoms at } \\
\text { metastasis }\end{array}$ & $\begin{array}{l}\text { Extrathoracic } \\
\text { metastatic site }\end{array}$ & $\begin{array}{l}\text { Thoracic } \\
\text { metastatic site }\end{array}$ & $\begin{array}{l}\text { Interval time } \\
\text { between diagnosis } \\
\text { and metastasis }\end{array}$ & $\begin{array}{l}\text { Single vs multiple } \\
\text { metastasis }\end{array}$ \\
\hline 70 & M & August-03 & A & $\mathrm{IVb}$ & $3.9 \mathrm{~cm}$ & SS & N/A & Right strap muscle & $\begin{array}{l}\text { Great vessels and } \\
\text { vagus nerve }\end{array}$ & M@P & M \\
\hline 44 & $\mathrm{M}$ & January-93 & B1 & IVb & N/A & MG & N/A & $\begin{array}{l}\text { Peritoneum, liver, } \\
\text { axilla, abdomen }\end{array}$ & $\begin{array}{l}\text { Lung, pleura, } \\
\text { pericardium }\end{array}$ & $\mathrm{M} @ \mathrm{P}$ & M \\
\hline 40 & $\mathrm{~F}$ & September-07 & B1 & $\mathrm{IVb}$ & N/A & Fibromyalgia & N/A & Liver & SVC obstruction & $\mathrm{M} @ \mathrm{P}$ & $\mathrm{M}$ \\
\hline 66 & M & July-10 & B1 & $\mathrm{I}$ & N/A & & SS & Retroperitoneum & $\begin{array}{l}\text { Pleura, hilum of } \\
\text { right lung }\end{array}$ & 17 years & $\mathrm{M}$ \\
\hline 37 & $\mathrm{~F}$ & N/A & B2 & N/A & N/A & N/A & N/A & Left biceps & N/A & N/A & M \\
\hline 56 & M & October-94 & B3 & III & $8.5 \mathrm{~cm}$ & MG & SS & Liver, trachea & Great vessels & 2 years & $\mathrm{M}$ \\
\hline 45 & $\mathrm{M}$ & June-87 & B1/B2 & $\mathrm{IVb}$ & N/A & $\begin{array}{l}\text { Ostealgia, CS, } \\
\text { SS }\end{array}$ & N/A & $\begin{array}{l}\text { Brain, scalp, L1-L3 } \\
\text { vertebrae, liver }\end{array}$ & Lung & M@P & $\mathrm{M}$ \\
\hline 39 & $\mathrm{~F}$ & February-05 & B2 & IVb & $17 \mathrm{~cm}$ & CS & N/A & Abdominal wall & Lung, pleura & $\mathrm{M} @ \mathrm{P}$ & $\mathrm{M}$ \\
\hline 31 & $\mathrm{M}$ & October-94 & B3 & $\mathrm{IVb}$ & N/A & CS & N/A & T10 vertebra, liver & Lung, pericardium & $\mathrm{M} @ \mathrm{P}$ & $\mathrm{M}$ \\
\hline 93 & $\mathrm{~F}$ & June-98 & B3 & II & $2.5 \mathrm{~cm}$ & CS & SS & Trachea, vocal cords & N/A & 6 years & $\mathrm{M}$ \\
\hline 45 & M & November-87 & B3 & IVa & N/A & MG & CS & $\begin{array}{l}\text { Liver, right/left } \\
\text { axillary nodes }\end{array}$ & $\begin{array}{l}\text { Pericardium, } \\
\text { pleura, sternum }\end{array}$ & 6 months & $\mathrm{M}$ \\
\hline 44 & $\mathrm{M}$ & N/A & B3 & N/A & N/A & N/A & CS & $\begin{array}{l}\text { Right kidney, } \\
\text { diaphraom }\end{array}$ & Lung & N/A & $\mathrm{M}$ \\
\hline 66 & M & November-87 & B3 & I & N/A & MG & CS & L1-vertebra, abdomen & $\begin{array}{l}\text { Lung, pleura, } \\
\text { pericardium }\end{array}$ & 2 years & M \\
\hline 39 & M & N/A & PD-SCC & N/A & N/A & N/A & N/A & Liver, lymph nodes & N/A & N/A & $\mathrm{M}$ \\
\hline 67 & M & November-87 & WD-SCC & $\mathrm{N} / \mathrm{A}$ & $11 \mathrm{~cm}$ & N/A & N/A & Liver & N/A & N/A & $\mathrm{S}$ \\
\hline 56 & $\mathrm{M}$ & August-03 & UND & $\mathrm{IVb}$ & N/A & $\mathrm{CS}$ & N/A & $\begin{array}{l}\text { Supraclavicular } \\
\text { lymph nodes, liver }\end{array}$ & N/A & $\mathrm{M} @ \mathrm{P}$ & $\mathrm{s}$ \\
\hline 79 & $\mathrm{M}$ & August-04 & PD-SCC & $\mathrm{IVb}$ & $9.6 \mathrm{~cm}$ & CS & N/A & $\begin{array}{l}\text { Left scalene lymph } \\
\text { node }\end{array}$ & N/A & $\mathrm{M} @ \mathrm{P}$ & $\mathrm{s}$ \\
\hline 52 & $\mathrm{~F}$ & September-02 & PD-SCC & $\mathrm{IVb}$ & $13 \mathrm{~cm}$ & CS & N/A & $\begin{array}{l}\text { Left axillary lymph } \\
\text { node, liver }\end{array}$ & Lung & M@P & M \\
\hline 40 & $\mathrm{~F}$ & June-07 & UND & IVb & $10 \mathrm{~cm}$ & SS & N/A & $\begin{array}{l}\text { Left supraclavicular } \\
\text { lymph node }\end{array}$ & $\begin{array}{l}\text { Lung, thoracic } \\
\text { vertebrae }\end{array}$ & $\mathrm{M} @ \mathrm{P}$ & $\mathrm{M}$ \\
\hline 40 & $\mathrm{~F}$ & February-03 & NEC & III & N/A & SS & N/A & Ovary and uterus & Lung & 3 years & $\mathrm{M}$ \\
\hline 38 & $\mathrm{~F}$ & May-10 & UND & $\mathrm{IVb}$ & N/A & $\mathrm{CS}, \mathrm{LN}+$ & N/A & $\begin{array}{l}\text { Left supraclavicular } \\
\text { lymph node, liver }\end{array}$ & Lung, pleura & M@P & $\mathrm{M}$ \\
\hline 37 & M & October-09 & UND & IVb & N/A & CS & N/A & Liver & N/A & $\mathrm{M} @ \mathrm{P}$ & $\mathrm{s}$ \\
\hline 46 & $\mathrm{M}$ & March-07 & UND & I & N/A & CS & Dysphagia & Liver & Lung & 2 years & s \\
\hline 58 & $\mathrm{~F}$ & March-05 & M-SS & IVb & N/A & $\begin{array}{l}\text { SS, left chest } \\
\text { wall }\end{array}$ & N/A & Axillary lymph nodes & $\mathrm{N} / \mathrm{A}$ & $\mathrm{M@P}$ & $\mathrm{s}$ \\
\hline 47 & M & October-95 & UND & N/A & N/A & SS & SS, LN+ & $\begin{array}{l}\text { Left cervical lymph } \\
\text { node, } \\
\text { retroperitoneum }\end{array}$ & N/A & N/A & S \\
\hline 57 & $\mathrm{M}$ & June-02 & NEC & $\mathrm{IVb}$ & $14 \mathrm{~cm}$ & CS & N/A & $\begin{array}{l}\text { Left cervical lymph } \\
\text { node }\end{array}$ & Lung & $\mathrm{M} @ \mathrm{P}$ & $\mathrm{s}$ \\
\hline 47 & $\mathrm{M}$ & December-06 & UND & N/A & N/A & N/A & N/A & $\begin{array}{l}\text { Left supraclavicular } \\
\text { area }\end{array}$ & N/A & N/A & N/A \\
\hline 44 & M & August-02 & Clear cell & $\mathrm{N} / \mathrm{A}$ & N/A & $\mathrm{LN}+$ & N/A & Bone, left hip & N/A & N/A & $\mathrm{M}$ \\
\hline 70 & $\mathrm{M}$ & July-10 & UND & N/A & N/A & SS, ataxia & N/A & Liver & N/A & N/A & $\mathrm{S}$ \\
\hline 23 & $\mathrm{~F}$ & February-03 & M-SS & II & $5.5 \mathrm{~cm}$ & CS, SS & $\mathrm{CS}$ & Brain & Lung & 1 year & $S$ \\
\hline 66 & M & January-03 & UND & IVb & $6 \mathrm{~cm}$ & CS, ataxia & N/A & $\begin{array}{l}\text { Brain, liver, kidney } \\
\text { and bone }\end{array}$ & N/A & M@P & M \\
\hline 54 & $\mathrm{M}$ & July-04 & UND & $\mathrm{IVb}$ & $6.7 \mathrm{~cm}$ & $\begin{array}{l}\text { CS, scalp } \\
\text { nodule }\end{array}$ & N/A & Brain & N/A & M@P & $\mathrm{s}$ \\
\hline 35 & M & February-11 & UND & I & $8 \mathrm{~cm}$ & SS & CS & Brain, diaphragm & Lung & 1 year & $\mathrm{M}$ \\
\hline 41 & $\mathrm{~F}$ & February-11 & NEC & IVb & N/A & SS & N/A & Liver & $\mathrm{N} / \mathrm{A}$ & $\mathrm{M@P}$ & M \\
\hline 40 & $\mathrm{~F}$ & February-11 & NEC & IVb & N/A & SS & SS & Liver & Lung & $\mathrm{M} @ \mathrm{P}$ & M \\
\hline
\end{tabular}

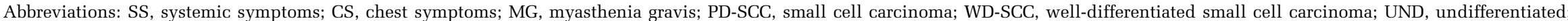
M-SS, mixed small cell and squamous cell carcinoma; NEC, neuroendocrine carcinoma; N/A, not available; M@P, metastatic at presentation. 

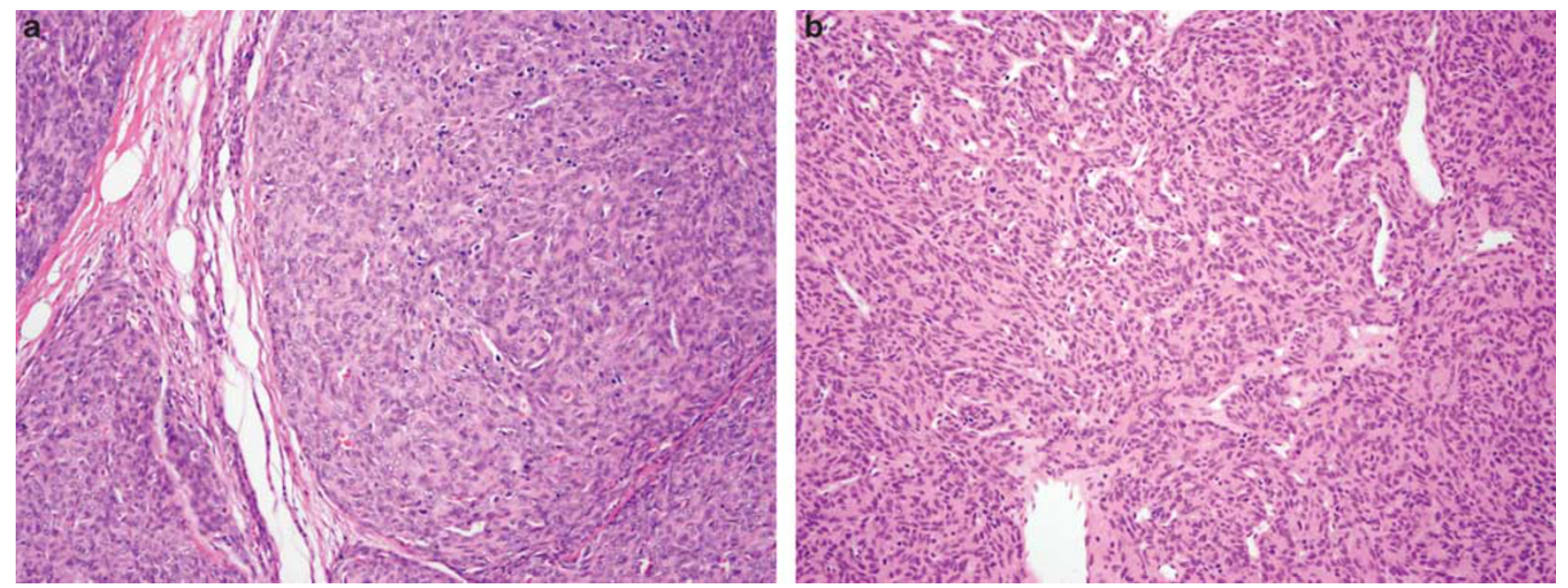

Figure 1 Type A thymoma with metastasis. The histological features of the primary tumor (a) are almost identical to that seen in the metastatic tumor (b). In both cases, the tumor is composed of a proliferation of round to ovoid cells with bland nuclei, open chromatin, and inconspicuous nucleoli. Small islands of tumor were surrounded by fibrous bands with prominent intervening blood vessels and rare scattered lymphocytes.
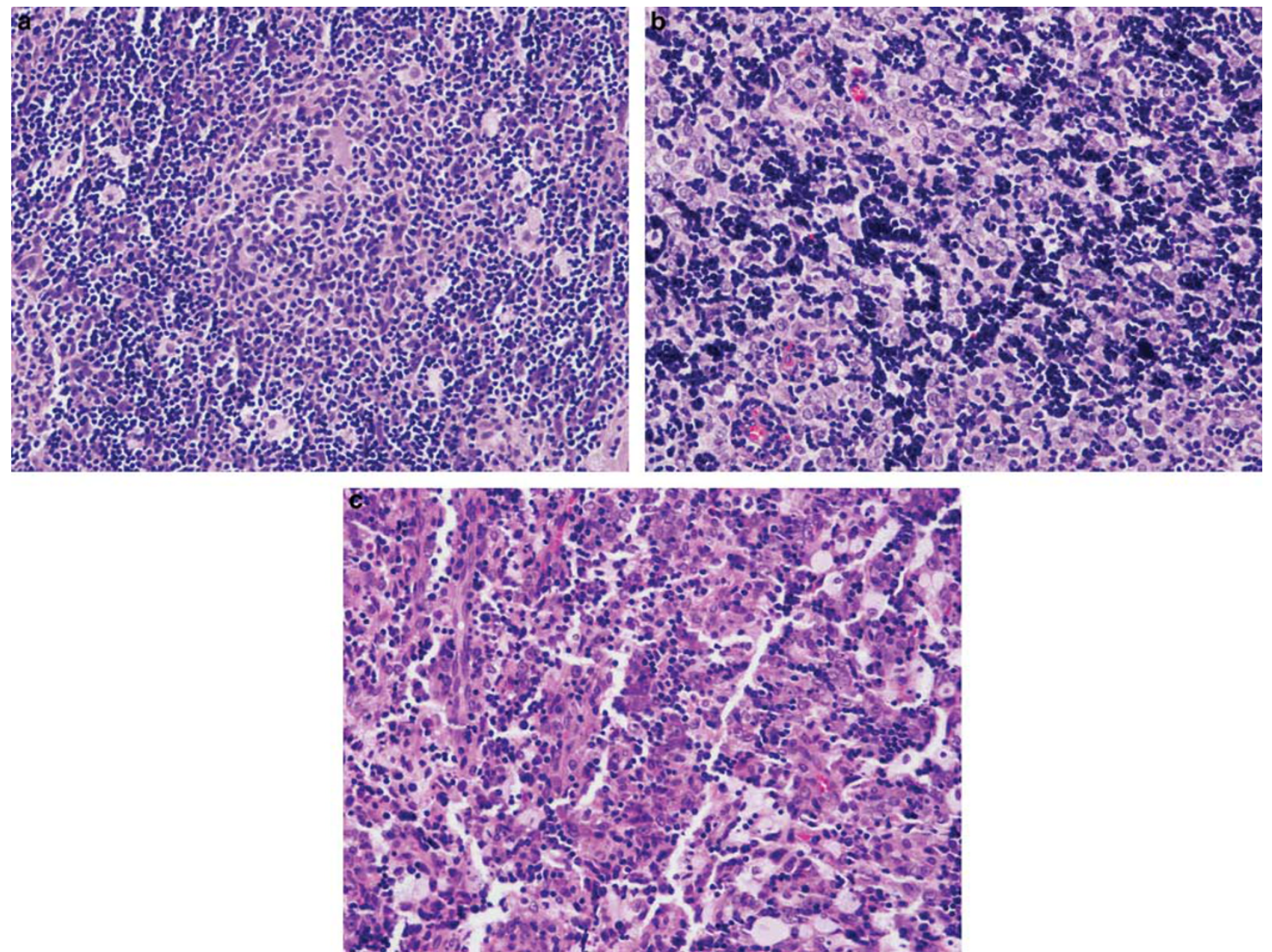

Figure 2 Type B1/B2 thymoma with metastasis showing lymphoid depletion. The primary tumor (core biopsy) shows greater numbers of lymphoid cells in both the B1 (a) and B2 areas (b) as compared with the metastases (c).

In nine patients who presented without synchronous metastasis, three patients had paraneoplastic syndromes, while the remainder presented with either systemic symptoms or symptoms related to localized effects of the tumor mass. These patients, when metastasis was confirmed, had either recurrence of 

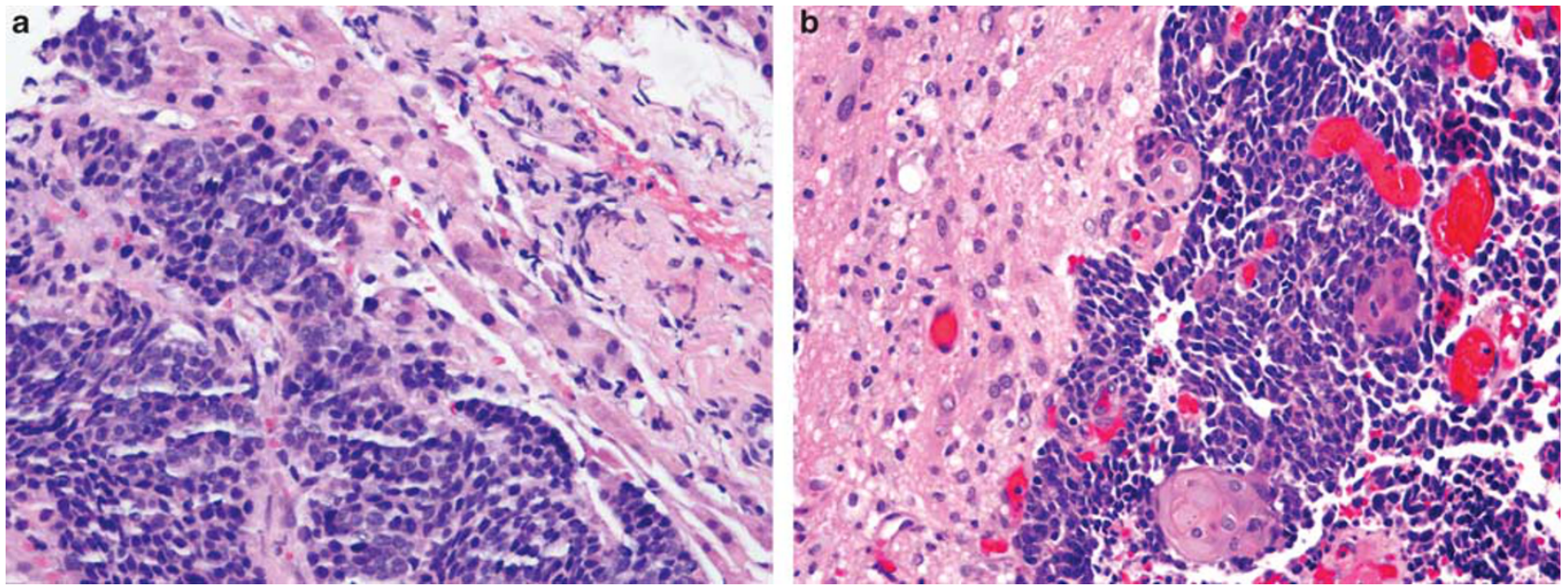

Figure 3 Microphotographs of liver metastasis from an undifferentiated carcinoma (a) and brain metastases from a mixed small cell squamous carcinoma (b) are shown.

systemic symptoms such as malaise, fatigue, weight loss, or abdominal pain/discomfort (two patients) or brain metastasis-related symptoms (two patients). In patients without synchronous tumors, the time interval from diagnosis of primary tumor to metastasis ranged from 6 months to 17 years. The average time to metastasis in these patients was 3.6 years.

Among the extrathoracic sites, lymph nodes were the most common site biopsied, with nine cases metastasizing to this site, followed by liver (eight cases) and soft tissue/skeletal muscles (four cases). Other areas of metastasis were bone, brain (Figure 3b), scalp, kidneys, meninges, parametrium, and abdominal wall.

\section{Discussion}

Thymoma and thymic carcinoma are rare tumors (annual incidence 1-5/million populations), which accounts for $\sim 40 \%$ of all mediastinal tumors. This rarity makes the recognition of a mediastinal tumor as being of thymic origin difficult; this is particularly true for thymic carcinomas. The recognition of thymic metastasis is even more challenging because of the rarity of extrathoracic metastasis (incidence is believed to be around $3-6 \%{ }^{9}$ ) and because the histology can mimic tumors from other sites. In addition, as thymic tumors are known to be associated with an increased risk for a second primary tumor; this raises a high suspicion for a second primary tumor instead of metastases. Several studies of thymoma patients reported frequent occurrence of second malignancies at diverse sites including breast, colon, leukemia and non-Hodgkin lymphoma, and carcinoid tumors. ${ }^{10-13}$

Bergh et al, ${ }^{14}$ in 1978, recognized that all thymic tumors can manifest malignant behavior and should be considered as malignant diseases. This is consistent with our findings that thymic tumors of all histologic types were associated with metastases, albeit with different frequencies. In the older literature, it was postulated that epithelial cells in the thymoma metastasize more frequently than the lymphocytic component, making the metastatic lesions predominantly of epithelial type. ${ }^{5}$ Nickels and Franssila ${ }^{6}$ reviewed 29 cases in the literature and concluded that metastatic thymoma of epithelial subtype was the most common type (67\%). They also showed that metastasizing thymoma was not histologically distinct from those that did not metastasize. Our studies (current and prior) confirm these findings. Review of the primary and metastatic tumors was possible in eight cases-two carcinomas and six thymomas. In all but one case, the histology of the metastatic tumor was identical to that of the primary tumor. In one case, the original tumor was diagnosed as B1/B2 type, while the metastatic tumor showed significant depletion of the lymphoid population with focal coalescence of the epithelial nests. Depletion or loss of lymphoid cells has been previously reported by Pescarmona et al. ${ }^{15}$ In their review of nine cases of recurrent thymomas, the histological features at recurrence were different from those observed at presentation in five of the cases. The authors ascribe this to the histological progression of disease. However, it is not known what the duration between last therapy and surgical excision or biopsy was in these cases. This is important since therapy, which often consisted of high doses of steroids, can cause lymphoid depletion. In addition, it should be kept in mind that the lymphoid-rich stroma seen in thymomas is probably a function of cytokine secretion and is likely to be an epiphenomenon rather than a sign of 'true progression.' The current classification of thymomas is heavily biased toward the character of this epiphenomenon rather than the character of the neoplastic cells. This could perhaps explain the difficulties in making prognostic assessments based on histology.

In our review of 35 cases, liver, lymph node, and soft tissue seem to be the most frequent metastatic 
sites. One of the 35 cases, in our review, was diagnosed as type A thymoma in both the primary and metastatic tumors. The behavior of type A thymomas is controversial; WHO (2004) categorically states that these are benign tumors. ${ }^{8}$ However, we have previously reported a large series of cases of type A tumors associated with aggressive intrathoracic disease. ${ }^{16}$ This has been more recently confirmed by Moran et al. ${ }^{17}$ In this light, it is important to note that brain metastasis has been reported ${ }^{18}$ in a patient with type A thymoma, which was histologically confirmed by Dr Rosai. In addition, the 10-year survival rates in patients with completely excised tumors and/or type A tumors have not always been $100 \% .{ }^{19-22}$ Type B thymomas are regarded as lowgrade neoplasms, where aggressive behavior somewhat correlated with the epithelial cellularity. In the five cases of type B thymomas with metachronous metastases, the epithelial cellularity somewhat correlated with the duration between diagnosis and development of extrathoracic metastasis; the duration being shorter for B3 types than for B1 types. In this respect, the data should be interpreted with caution as some of the diagnoses of B1 and B2 thymomas were made solely on the basis of needle core biopsies. It has been well documented that thymic neoplasms can exhibit an admixture of histological types in a significant number of cases. $^{8,23,24}$ Thymic carcinomas had the shortest duration between diagnoses to metastases, confirming their aggressive behavior.

Metastasis of malignant thymoma or thymic carcinoma has been reported in the liver, lymph node, bone, brain, gastrointestinal tract, kidney, ovary, spleen, adrenal, pancreas, skin, breast, and nervous system other than cerebrum. ${ }^{1,2,4-6,9,25-28}$ The differential diagnosis of the metastatic thymic tumor varies with the site of metastasis. Metastases from a type A thymoma can be confused with spindle cell carcinomas or mesenchymal tumors like hemangiopericytoma. Stains for keratins and CD20 can be very useful in this situation. Types B1 and B2 thymomas may be mistaken for a 'small blue cell tumor,' particularly in a limited biopsy specimen collected from a metastatic tumor. The presence of keratin-positive cells admixed with lymphoid cells that express CD3 is useful in the distinction. Epidermal growth factor receptor is often expressed in thymomas and can be of assistance in difficult cases. As with any other tumor, the availability of clinical history of thymic neoplasm is a very important clue.

Depending on metastatic site, a differential diagnosis for metastatic type B3 thymoma is quite difficult. B3 thymomas in contrast to B1 and B2 thymomas are lymphocyte poor. Epithelial cells form confluent sheets or extensive solid areas that may present focal spindle cell formation, focal loss of intraepithelial lymphocytes, and clear cell changes. These features can raise a suspicion for a low-grade renal cell carcinoma. The epithelioid cells in type B3 thymoma are keratin AE1/AE3 positive and may express EMA positivity but they are negative for vimentin. Importantly, the sinusoidal vasculature that characterizes renal cell carcinoma is not present in B3 thymoma. In addition, intermixed lymphocytes are all immature in type B thymoma (positive CD1a, TdT, and CD99).

In our review, we found 22 cases of thymic carcinoma including 11 undifferentiated carcinomas, 4 cases of squamous cell carcinoma (with 2 cases showing focal keratinization), 4 neuroendocrine tumors, 2 mixed small cell and squamous cell carcinomas, and 1 rare variant of metastatic thymic clear cell carcinoma. Most of the cases of undifferentiated carcinomas in this series had a lymphoid-rich stroma, raising the differential diagnosis of lymphoepithelioma. A metastatic neuroendocrine tumor can cause significant issues with respect to site of origin as these tumors have a phenotype more or less similar to the ones originating in the lung and gastrointestinal tract. Neuroendocrine tumors of the thymus are aggressive neoplasms associated with nodal metastases and poor prognosis despite their occasionally well-differentiated, bland appearance. ${ }^{29-31}$ This aggressive behavior, along with a strong immunoreactivity for a broad spectrum of keratins (AE1/AE3 and CAM 5.2), makes them easily misinterpreted as carcinoma especially on biopsy specimen.

Metastatic squamous cell carcinoma of the thymus should also be distinguished from squamous cell carcinoma of other mediastinal organs, such as lung and esophagus. Thymic squamous cell carcinoma is characterized by broad fibrotic-hyalinized stroma and a lack of radial pattern of cells at the periphery of tumor nest, commonly seen in bronchogenic carcinoma. However, in poorly differentiate tumors, FOXN1, CD205, CD5, CD70, and CD117 can assist the recognition of thymic origin. ${ }^{32}$ It should be noted that none of these markers are specific. CD5 can focally be expressed in type B3 thymoma, urothelial carcinoma, malignant mesothelioma, and adenocarcinoma of various organs; ${ }^{33}$ CD70 may be positive in renal cell carcinoma, nasopharyngeal carcinoma, and Hodgkin lymphoma. ${ }^{34}$

Clear cell carcinoma of the thymus is exceedingly rare; ${ }^{35-38}$ we have only seen two cases in our database of $\sim 120$ thymic carcinomas. In addition to renal clear cell carcinomas, metastatic germ cell tumors (particularly seminoma), large B cell lymphoma, clear cell sarcoma or melanoma, and clear cell paraganglioma should be considered in the differential diagnosis. Appropriate clinical history and a panel of immunostains may be required to arrive at the correct diagnosis.

\section{Conclusion}

We have described 35 cases of thymic tumors with extrathoracic metastatic extension. The most common subtype associated with metastasis was 
thymic carcinoma, followed by type B tumors. The most common metastatic sites biopsied were lymph node, followed by liver and soft tissue (skeletal muscle, retroperitoneal fat). Metastases morphologically closely resembled the primary tumor.

\section{Acknowledgement}

We would like to acknowledge Tracey Bender for secretarial assistance.

\section{Disclosure/conflict of interest}

The authors declare no conflict of interest.

\section{References}

1 Youk JH, Kim EK, Kim MJ, et al. Metastatic breast lesion from thymic carcinoma. J Ultrasound Med 2006;25:1339-1342.

2 Walid MS, Troup EC, Robinson Jr JS. Brain metastasis from thymic carcinoma in association with SIADH and pituitary enlargement: a case report. South Med J 2008;101:764-766.

3 Suster S, Moran CA. Thymoma classification: current status and future trends. Am J Clin Pathol 2006;125:542-554.

4 Guillan RA, Zelman S, Smalley RL, et al. Malignant thymoma associated with myasthenia gravis, and evidence of extrathoracic metastases. An analysis of published cases and report of a case. Cancer 1971; 27:823-830.

5 Ichino Y, Obuchi M, Suko K, et al. Malignant thymoma with distant metastases: a case report and review of the literature. Jpn J Clin Oncol 1983;13:733-739.

6 Nickels J, Franssila K. Thymoma metastasizing to extrathoracic sites. A case report. Acta Pathol Microbiol Scand A 1976;84:331-334.

7 Huang J, Rizk NP, Travis WD, et al. Comparison of patterns of relapse in thymic carcinoma and thymoma. J Thorac Cardiovasc Surg 2009;138:26-31.

8 Travis WD, World Health Organization, International Agency for Research on Cancer, International Association for the Study of Lung Cancer, International Academy of Pathology. Pathology and Genetics of Tumours of the Lung, Pleura, Thymus and Heart, 1st edn. IARC Press/Oxford University Press (distributor): Lyon/Oxford, 2004.

9 Bott-Kothari T, Aron BS, Bejarano P. Malignant thymoma with metastases to the gastrointestinal tract and ovary: a case report and literature review. Am J Clin Oncol 2000;23:140-142.

10 Pan CC, Chen PC, Wang LS, et al. Thymoma is associated with an increased risk of second malignancy. Cancer 2001;92:2406-2411.

11 Souadjian JV, Silverstein MN, Titus JL. Thymoma and cancer. Cancer 1968;22:1221-1225.

12 Welsh JS, Wilkins KB, Green R, et al. Association between thymoma and second neoplasms. JAMA 2000;283:1142-1143.

13 Engels EA, Pfeiffer RM. Malignant thymoma in the United States: demographic patterns in incidence and associations with subsequent malignancies. Int J Cancer 2003;105:546-551.

14 Bergh NP, Gatzinsky P, Larsson S, et al. Tumors of the thymus and thymic region: I. Clinicopathological studies on thymomas. Ann Thorac Surg 1978;25: 91-98.

15 Pescarmona E, Rendina EA, Venuta F, et al. Recurrent thymoma: evidence for histological progression. Histopathology 1995;27:445-449.

16 Jain RK, Mehta RJ, Henley JD, et al. WHO types A and AB thymomas: not always benign. Mod Pathol 2010;23:1641-1649.

17 Moran CA, Kalhor N, Suster S. Invasive spindle cell thymomas (WHO Type A): a clinicopathologic correlation of 41 cases. Am J Clin Pathol 2010;134:793-798.

18 Gamboa EO, Sawhney V, Lanoy RS, et al. Widespread metastases after resection of noninvasive thymoma. J Clin Oncol 2008;26:1752-1755.

19 Kondo K, Yoshizawa K, Tsuyuguchi M, et al. WHO histologic classification is a prognostic indicator in thymoma. Ann Thorac Surg 2004;77:1183-1188.

20 Okereke IC, Kesler KA, Morad MH, et al. Prognostic indicators after surgery for thymoma. Ann Thorac Surg 2010;89:1071-1077; discussion 1077-1079.

21 Rieker RJ, Muley T, Klein C, et al. An institutional study on thymomas and thymic carcinomas: experience in 77 patients. Thorac Cardiovasc Surg 2008; 56:143-147.

22 Suster S, Rosai J. Thymic carcinoma. A clinicopathologic study of 60 cases. Cancer 1991;67:1025-1032.

23 Moran CA, Suster S. On the histologic heterogeneity of thymic epithelial neoplasms. Impact of sampling in subtyping and classification of thymomas. Am J Clin Pathol 2000;114:760-766.

24 Moran CA, Suster S. The World Health Organization (WHO) histologic classification of thymomas: a reanalysis. Curr Treat Options Oncol 2008;9:288-299.

25 Brown RC, Cohen WN, Rose EF. Malignant thymoma with penetration into the gastrointestinal tract: report of two cases. South Med J 1976;69:409-412, 429.

26 Needles B, Kemeny N, Urmacher C. Malignant thymoma: renal metastases responding to cis-platinum. Cancer 1981;48:223-226.

27 Ahn JY, Kim NK, Oh D, et al. Thymic carcinoma with brain metastasis mimicking meningioma. J Neurooncol 2002;58:193-199.

28 Sait SN, Brooks JJ, Ashraf $\mathrm{M}$, et al. A novel $\mathrm{t}(1 ; 8)(\mathrm{p} 13 ; \mathrm{p} 11)$ in a thymic carcinoma with unusual giant cell features and renal metastasis. Cancer Genet Cytogenet 2001;124:140-143.

29 Klemm KM, Moran CA. Primary neuroendocrine carcinomas of the thymus. Semin Diagn Pathol 1999; 16:32-41.

30 Moran CA, Suster S. Neuroendocrine carcinomas (carcinoid tumor) of the thymus. A clinicopathologic analysis of 80 cases. Am J Clin Pathol 2000;114: 100-110.

31 Wick MR, Rosai J. Neuroendocrine neoplasms of the thymus. Pathol Res Pract 1988;183:188-199.

32 Nonaka D, Henley JD, Chiriboga L, et al. Diagnostic utility of thymic epithelial markers CD205 (DEC205) and Foxn1 in thymic epithelial neoplasms. Am J Surg Pathol 2007;31:1038-1044.

33 Tateyama H, Eimoto T, Tada T, et al. Immunoreactivity of a new CD5 antibody with normal epithelium and malignant tumors including thymic carcinoma. Am J Clin Pathol 1999;111:235-240. 
34 Junker K, Hindermann W, von Eggeling F, et al. CD70: a new tumor specific biomarker for renal cell carcinoma. J Urol 2005;173:2150-2153.

35 Nakano T, Endo S, Tsubochi H, et al. Thymic clear cell carcinoma. Gen Thorac Cardiovasc Surg 2010;58: 98-100.

36 Hasserjian RP, Klimstra DS, Rosai J. Carcinoma of the thymus with clear-cell features. Report of eight cases and review of the literature. Am J Surg Pathol 1995; 19:835-841.

37 Wolfe III JT, Wick MR, Banks PM, et al. Clear cell carcinoma of the thymus. Mayo Clin Proc 1983;58: 365-370.

38 Snover DC, Levine GD, Rosai J. Thymic carcinoma. Five distinctive histological variants. Am J Surg Pathol 1982;6:451-470. 